\title{
Determinant of Nurses' Response Time in Emergency Department When Taking Care of A Patient
}

Indonesian Nursing Journal of Education and Clinic (INJEC)

125-133

Volume 5, Issue 2, December 2020

DOI: I0.24990/injec.v5i2.305

injec.aipni-ainec.org/index.php/INJEC/index

Received : 2020-06-09

Accepted : 2020-07-24

The Association of Indonesian Nurse

Education Center (AINEC)

\section{Dwi Yanti Rachmasari Tartila' ${ }^{\mathbb{D}}$, Andri Setiya Wahyudi' ${ }^{\mathbb{D}}$, Arina Qona'ah'}

\begin{abstract}
Introduction: : Response time is the handling speed calculated when the patients arrive at the hospital until they are treated. It is influenced by several factors according to Gibson Performance Theory. The research approach aimed to analyze individual factors including: skills, emergency training, gender, age, length of working, and education, organizational factors: rewards, and psychological factors: nurse motivation that influences the response time of the nurses in emergency departments at general hospitals in Madura.

Methods: The research method used was a descriptive-analytic study with a cross-sectional approach. The sampling technique is total sampling, which is $10 \mathrm{I}$ nurses. Independent variables are skills, emergency training, gender, age, length of working, education, rewards, and motivation. Dependent variable is response time. Data were collected using a questionnaire and direct observations on nurses, data were analyzed using the Multiple Regression Logistic test.

Results: The results show that there was no correlation between age $(p=0.996)$; education $(p=$ $0.913)$; length of working $(p=0.921)$; training $(p=0.830)$; skill factor $(p=0.999)$; and motivation factors $(p=0.47 \mathrm{I})$ with response time. Whereas gender $(p=0.020)$; and reward factor $(p=0.020)$ were related with response time.

Conclusion: In order to improve patients' handling procedure, hospitals should give support to nurses, like promotion or salary. Hospitals are expected to record documentations about the number of patients according to triage category and how fast nurses handle them because it may be an evaluation for rooms.
\end{abstract}

\section{Keywords}

gender; motivation; response time; reward; skill

\section{INTRODUCTION}

Nursing services are an integral part of health services; one of the places of service in hospitals is the Emergency Department (ED) which is a central unit of the hospital that functions as the main door in handling emergency cases (Yumiati, 2017). Services in the ED have the philosophy of Time-Saving it's Life-Saving, which means time is the life of the patient. Therefore, all emergency measures are carried out effectively and efficiently. Triage used in Indonesian hospitals is a color triage

\footnotetext{
' Faculty of Nursing, Airlangga University

Corresponding Author:

Andri Setiya Wahyudi, Department of Fundamental Nursing, Faculty of Nursing, Airlangga University, Surabaya, Indonesia Universitas Airlangga Kampus C, Jl. Mulyorejo, Mulyorejo, Surabaya, Kota SBY, Jawa Timur 60115 Email: andry_remas@yahoo.co.id
} 
system. Red triage means that emergency patients need treatment as soon as possible, yellow triage is emergency patients, and green triage means low levels of emergency and can still wait for treatment.

Factors affecting response time include internal and external factors, which may affect tardiness on handling emergency cases. Furthermore, response time might also be affected by patient's character, staff positioning, stretcher and medical staff availability, patient's arrival time, implementation of management, as well as chosen examination and handling strategy (Wa \& Ode, 20I2).

Response time is the speed of treatment that is calculated when the patient arrives at the hospital until the patient is treated. Response time is categorized with several priorities, including $\mathrm{PI}(\mathrm{Red})$ for emergency patients with a treatment time of 0 minutes, P2 (Yellow) for emergency patients with a treatment time of less than 30 minutes, and P3 (Green) for low emergency patients with a treatment time of less than 60 minutes (Permenkes, 20I8).

Based on previous studies that have been conducted by researchers from 29-30 November, 2019, it was found that there were 21 nurses in ED of Sumenep Hospital. The lowest level of study is associate degree as many as 16 nurses, Bachelor's degree as many as four nurses, and postgraduate (S2) only one nurse. The number of ED patient visits in 2018 was 12,000 patients with the number of new patient visits of $6,96 \mathrm{I}$ patients. Whereas in 2019 , from January to November, there were 10,523 patients with a total of 5,893 new patients. The average number of patients per day is 30 patients, so the minimum number of nurses is 25 nurses if calculated based on the formula of nurses needed in the emergency room. This shows that the number of nurses in ED of Sumenep Hospital has not met the minimum requirements.

Some previous references showed that tardiness on handling patients was still found at some hospitals in Indonesia. A research by Noor (2009) that talked about time response on handling patients in Emergency Department (ED) showed 7.45 minutes of response time, which was the contrary of critical care indicators, in which the response time for critical patients, or $\mathrm{PI}$, must be less than 0 minute. Similar research was done by Vitrise
(2014) about the factors that affect nurses' response time in Prof. Dr. R.D. Kandao Manado's Hospital in ED and showed that there were 17 nurses with $>5$ minutes response time.

Gibson's theory is divided into three factors that can influence nurse performance, including individual factors, psychological factors, and organizational factors. Individual factors consist of ability, skills, education, length of work, age, and gender. Psychological factors consist of perception, attitude, personality, learning, and motivation, while organizational factors consist of resources, leadership, structure, job design, and rewards. The reason of using Gibson's performance theory in the research is because it was easy to understand and Gibson explained factors that may affect nurses' performance, which is response time. The purpose of this study is to determine the factors that influence emergency department nurses in handling patients based on Gibson's Performance Theory.

\section{MATERIALS AND METHODS}

The research design used was descriptiveanalytic with cross-sectional approach. This research was carried out January to March 2020, in the EDs of Madura General Hospital, such as Bangkalan General Hospital, Sampang General Hospital, Mohammad Noer Pamekasan General Hospital, and Sumenep General Hospital. The sampling technique of this study was total sampling, that is, all nursing staff who served in EDs of Madura General Hospital, as many as $10 \mathrm{I}$ nurses. Independent variables are skills, emergency training, gender, age, length of working, education, rewards, and motivation. The questionnaire ability has been tested in validity and reliability by Yumiati (2017) in which questionnaire ability $r$ value was between 0.919 to 0.943 and Cronbach's alpha value was 0.934 . The questionnaire uses a Likert scale that consists of 10 questions. The reward questionnaire by Yumiati (20I7) shows validity test for reward questionnaire gives a result 0.829 on $r$ value and reliability test shows Cronbach's alpha value of 0.860 . The questionnaire uses Likert scale with indicators of financial, interpersonal, and promotion divided into 12 questions. On the other hand, the motivation questionnaire by Yumiati (2017) 
Table I. Characteristic Demographic $(n=|0|)$

\begin{tabular}{|c|c|c|}
\hline Category & Frequency & $(\%)$ \\
\hline \multicolumn{3}{|l|}{ Age } \\
\hline $17-25$ years old & 5 & 5 \\
\hline 26-35 years old & 66 & 65.3 \\
\hline $36-45$ years old & 28 & 27.7 \\
\hline 46-55 years old & 2 & 2 \\
\hline \multicolumn{3}{|l|}{ Gender } \\
\hline Male & 69 & 68.3 \\
\hline Female & 32 & 31.7 \\
\hline \multicolumn{3}{|l|}{ Education } \\
\hline Diploma 3 & 50 & 49.5 \\
\hline Bachelor of Nursing & 49 & 48.5 \\
\hline Master of Nursing & 2 & 2 \\
\hline \multicolumn{3}{|l|}{ Length of working } \\
\hline$<5$ years & 44 & 43.6 \\
\hline $5-10$ years & 47 & 46.5 \\
\hline$>10$ years & 10 & 9.9 \\
\hline \multicolumn{3}{|l|}{ Training } \\
\hline Triage & 2 & 2 \\
\hline Emergency & 97 & 96 \\
\hline Lain-lain & 2 & 2 \\
\hline \multicolumn{3}{|l|}{ Ability } \\
\hline High (76-100\%) & 98 & 97 \\
\hline Medium (56-75\%) & 3 & 3 \\
\hline \multicolumn{3}{|l|}{ Salary } \\
\hline High (76-100\%) & 13 & 12.9 \\
\hline Medium (56-75\%) & 56 & 55.4 \\
\hline Low $(<55 \%)$ & 32 & 31.7 \\
\hline \multicolumn{3}{|l|}{ Motivation } \\
\hline High (75-10\%) & 90 & 89.1 \\
\hline Medium (56-75\%) & 11 & 10.9 \\
\hline \multicolumn{3}{|l|}{ Triage P1 } \\
\hline Fast & 68 & 57.3 \\
\hline Slow & 33 & 32,7 \\
\hline \multicolumn{3}{|l|}{ Triage P2 } \\
\hline Fast & 87 & 86.1 \\
\hline Slow & 14 & 13.9 \\
\hline \multicolumn{3}{|l|}{ Triage P3 } \\
\hline Fast & 91 & 90.1 \\
\hline Slow & 10 & 9.9 \\
\hline
\end{tabular}

gives a value of 0.803 to 0.852 on $r$ value and Cronbach's alpha of 0.839 . Those 12 questions include need for achievement aspect, affiliation aspect, and need for power.

Other than that, this research instrument also uses researcher's direct observation at Bangkalan Hospital February 6th - 10th, 2020, Sampang Hospital February 12th - 19th, 2020, and Sumenep Hospital March 2nd - 9th, 2020. There was also research at Mohamman Noer Hospital March 16th-22nd, 2020. The researchers did the research on morning shift at about $07.00 \mathrm{am}$ to $2.00 \mathrm{pm}$, except for Mohammad Noer Hospital that occurred on afternoon shift at $2.00 \mathrm{pm}$ to $8.00 \mathrm{pm}$ because the decreasing patients during the corona pandemic. Researchers observed by counting the time between patient's arrival time until the patient was handled thoroughly. When patients came, they would be categorized by the triage PI(Red), P2 (Yellow), or P3 (Green). Then, patients would be sent to cubical curtains that had been marked red, yellow, or green. Every nurse was only once observed for each triage. So, every nurse would be observed on how they handled each triage. The researcher knew the triage category of each patient after they had been examined by doctor and nurse, then patients would be taken to the cubicle that marked with each color or triage. Furthermore, questionnaire data and observations were collected and analyzed using the Multiple Regression Logistic test with $\alpha=$ 0.05 . This research has been ethically tested by the Health Services Ethics Committee (KEPK) 
Table 2. Result of Variables in the Equation

\begin{tabular}{|c|c|c|c|}
\hline \multirow{2}{*}{ Variable } & \multirow{2}{*}{ Sig. } & \multicolumn{2}{|c|}{ 95\% C.I for $\operatorname{Exp}(B)$} \\
\hline & & Lower & Upper \\
\hline \multicolumn{4}{|c|}{ Correlation between Factors Related to Response Time P1 (Red) } \\
\hline Age & 0.996 & & \\
\hline Gender & 0.020 & 1.228 & 11.582 \\
\hline Education & 0.913 & & \\
\hline Length of Work & 0.921 & & \\
\hline Training & 0.830 & & \\
\hline Ability & 0.999 & & \\
\hline Reward & 0.020 & & \\
\hline Motivation & 0.471 & & \\
\hline \multicolumn{4}{|c|}{ Correlation between Factors Related to Response Time P2 (Yellow) } \\
\hline Age & 0.990 & & \\
\hline Gender & 0.702 & 0.198 & 0.2978 \\
\hline Education & 0.142 & & \\
\hline Length of Work & 0.962 & & \\
\hline Training & 1.000 & & \\
\hline Ability & 0.999 & $1.642 \mathrm{E} 8$ & 0.000 \\
\hline Reward & 0.316 & & \\
\hline Motivation & 0.506 & 0.194 & 27.897 \\
\hline \multicolumn{4}{|c|}{ Correlation between Factors Related to Response Time P3 (Green) } \\
\hline Age & 0.649 & & \\
\hline Gender & 0.597 & 0.108 & 3.600 \\
\hline Education & 0.741 & & \\
\hline Length of Work & 0.651 & & \\
\hline Training & 0.171 & & \\
\hline Ability & 0.475 & 0.006 & 11.134 \\
\hline Reward & 0.955 & & \\
\hline Motivation & 0.304 & 0.036 & 2.824 \\
\hline
\end{tabular}

of the Faculty of Nursing, Airlangga University. Ethical approval No. 1897-KEPK.

\section{RESULTS}

Based on Table I, it can be seen that, from IOI total number of nurses in ED from Madura General Hospital, the highest frequency of nurses is at the age of 26-35 years, as many as 66 nurses. Based on gender, the majority were male with 69 nurses. The level of education of nurses with Diploma 3 is 50 nurses. Based on the length of work, it was found 47 nurses had worked for 5-10 years. Furthermore, based on the training factor, there were 97 nurses in ED who had attended emergency training.

Of the I0I nurses, most of them (98) had a high ability level. In the high motivation factor category, there were 90 nurses. For response time, in the PI triage (Red), there were 68 nurses doing fast response times ( $<60$ seconds) and 33 nurses doing slow response times $(>60$ seconds). Whereas in the P2 triage (Yellow), there were 87 nurses doing fast response times, and there were 14 nurses doing slow response times ( $>30$ minutes). Furthermore, for P3 triage (Green), there were 91 nurses doing fast response times (<60 minutes) and 10 nurses doing slow response times ( $>60$ minutes).

Analysis of the Relationship between Factors Related to Response Time

Table 2. Hypothesis Test Results from the Relationship of Age, Gender, Education, Length of Work, Training, Ability, Salary, and 
Motivation with the Response Time Nurses in ED Bangkalan Hospital, Sampang Hospital, Mohammad Noer Hospital Pamekasan, and Sumenep Hospital.

Based on Table 2, the result of variable in the equation table in gender category shows the value $\mathrm{Sig}=0.020$. Because the value Sig $\alpha<0,05, \mathrm{H} 0$ is rejected and the conclusion is gender is related to response time $\mathrm{PI}$ (Red). In the reward factors based on the results obtained, Sig $=0.020$; because Sig $\alpha<0.05$ the conclusion is the reward factor is related to response time $\mathrm{PI}$ (Red).

Based on the table, it shows the results of correlation between factors related to response time P2 (Yellow) where the value Sig $\alpha>0.05$ for all factors. So, the conclusion is individual factors, organization, and psychological factors do not have significant correlation with response time P2 (Yellow).

Furthermore, the table shows that the results of the multiple regression for all factors to response time P3 (Green) that value Sig $\alpha>0.05$, so it can be concluded that there is no correlation between individual factors, organizational factors, and psychological factors with response time P3 (Green).

\section{DISCUSSIONS}

\section{Analysis of the Relationship between Individual Factors and Response Time}

Based on the results of the study, it was found that age does not have a significant relationship with the response time. This is because nurses must have the ability to handle patients quickly and appropriately; nurses will always update their knowledge by attending training so that there is no difference between young and old. However, this is contrary to Gibson's performance theory which reveals that age is related to nurse performance in terms of nurse response time. In addition, the average age of respondents is 25-35 years, which means entering early adulthood. In this age range, respondents are familiar with carrying out their obligations and duties, so that at the age of 25-35 years will not experience in handling serious patients in the ED.

Based on the results of statistical tests, it can be concluded that there is a relationship between sex with $\mathrm{PI}$ response time, but gender is not related to $\mathrm{P} 2$ and $\mathrm{P} 3$ response time. These results are consistent with Gibson's performance theory which reveals that sex is related to nurses' response time in handling patients, especially for PI triage response time. Most of the respondents' sex is male. This is because the duties of nurses in ED must have the ability in terms of speed and accuracy. Gender is related to response time $\mathrm{PI}$. This is because, in the PI triage, the time required in handling patients is $<60$ seconds, so more male nurses are needed than females. Whereas in $\mathrm{P} 2$ and $\mathrm{P} 3$, the time needed by nurses is quite long, i.e. $<45$ minutes for $\mathrm{P} 2$ and $<60$ minutes for $\mathrm{P} 3$ so that it can be done by female nurses.

Based on the results of the study, there was no significant relationship between education and nurse response time in handling patients. This research contradicts Gibson's theory which reveals that the education level of respondents can affect the response time. Research conducted by Yumiati (2017) also found that there was no relationship between education and response time $(p=0.360)$. Another study by Vitrise (2014) also found that there was no relationship between education and response time $(p=0.084)$. The education level of nurses that are low or high will have a good response time because nursing graduates already have the skills to be able to do nursing care based on nursing ethics and have mastered nursing during the lectures. In Setiawan (2015), it was stated that health workers in the Emergency Department (ED) must have an element of readiness, including the readiness of science and skills in handling patients. Therefore, the higher level of education of nurses does not affect the level of speed in responding time.

Based on the results of the study, there was no significant relationship between the length of work with nurses' response time in handling patients. This is not in accordance with Gibson's performance theory which revealed that the length of work could be related to the response time of nurses in handling patients. This study is also the same as Yumiati (2017) that the length of service of nurses has no significant relationship with response time $(p=0.483)$. Another study by Vitrise (20I4) also revealed that there was no relationship between work duration and 
response time $(p=0.119)$. Due to the length of time, most respondents work in this study is 5 - 10 years, it can be said that nurses have quite a long experience in handling patients. According to Yumiati (2017), there is no difference between nurses' length of work because they have been given training. Therefore, the longer the nurse works cannot be used as a benchmark to make the response time quickly.

The training factor is not related to response time. This study is not the same as Gibson's performance theory which states that the training followed by nurses is related to the nurse's response time in patient handling. Research conducted by Vitrise (2014) also revealed that there was no relationship between training and response time ( $P=$ $0.255)$. This can happen because most nurses have attended emergency training so that it can facilitate nurses to provide treatment to patients. The training is carried out periodically a maximum of once every five years so that ED nurses can improve their knowledge by attending the training.

Based on the results of statistical tests, the ability factor is not related to the nurse's response time. This research contradicts Gibson's performance theory which reveals that the ability of respondents can increase response time. According to Gibson, the ability is one element of maturity related to knowledge and skills in handling patients, which can be obtained from education, training and work experience. This study is the same as Yumiati (2017), whose research results show that there is no significant relationship between ability and response time $(p=0.414)$. Thus, the level of ability of respondents is not related to the level of speed in carrying out their duties.

\section{Analysis of Relationship between Organizational Factors and Response Time}

On organizational factors, salary factors, the results of the research show that there is a relationship between the reward factor with the triage response time PI. If nurses want to be seen as achievers, they must do the work quickly and precisely so that they can relate to $\mathrm{PI}$ triage because the response time on $\mathrm{PI}$ triage is quite short, i.e. $<60$ seconds, while for $\mathrm{P} 2$ and P3 triage, it takes a long time. This is the same as Gibson's performance theory which states that the higher the nurse's reward can increase the nurse's response time in handling patients in the ED. According to Gibson, salaries are divided into two, namely intrinsic and extrinsic salaries. Intrinsic salary is an award given by oneself, such as the achievements one has achieved. Extrinsic salaries are external rewards such as financial rewards, in the form of money and benefits. Research conducted by Yumiati (2017) also says that there is a relationship between salary factors with response time and values $(p=$ 0.003).

This shows that the higher the salary of nurses, the faster the handling of patients. This is indicated by the burden of nurses in ED that is not proportional to the salary earned by nurses. According to Yumiati (2017), low nurse salaries have a longer response time than those who get high salaries. Based on the results of the questionnaire with the lowest score, respondents revealed that respondents did not get an award from the leadership for their work performance, did not get a promotion at the time of achievement, and respondents did not get a bonus from the hospital when performing. So, there is a need for further evaluation related to the rewards given by nurses in order to improve the performance of nurses in handling patients. Therefore, it can be concluded that the higher the rewards or rewards given, the higher the respondents in completing their work.

Analysis of the Relationship between Psychological Factors and Response Time

In psychological factors, motivational factors, it was found that there was no relationship between motivational factors with response times $\mathrm{PI}, \mathrm{P} 2$, or $\mathrm{P} 3$. This is because room nurses are still reluctant to read books or look for references. Researchers found that only a few nurses in each hospital had a desire to read nursing books in their free time. Based on the results of the questionnaire, there are still many nurses who do not like looking for books or references on clinical skills to add knowledge and insight to nurses. It can explain that respondents still do not have a high enthusiasm to renew new skills and knowledge that are developing at this time. This research is contrary to Gibson's performance theory which reveals that motivational factors can be 
related to response time. However, this study is the same as Yumiati (2017), which states that there is no relationship between motivational factors and response time $(p=0.320)$.

According to Gibson, motivation is a person's desire to get things done or a desire to be better at doing work. Motivation has three main elements, namely, needs, encouragement, and goals. Motivation can occur if desires are not in accordance with reality, so motivation aims to encourage someone to be able to realize their desires. This can explain that respondents still do not have a high enthusiasm to renew new skills and knowledge that are developing at this time. According to Ratna (2007 cited in Nursalam, 2015), performance is one's efforts plus the work of someone so that it can be formulated as $\mathrm{P}$ (performance) $=\mathrm{E}$ (effort) $+\mathrm{A}$ (achievement). Therefore, to improve the quality of nursing services also requires nurse motivation and proper appreciation from the hospital.

\section{CONCLUSION}

Individual factors, including age, sex, education, length of work, and training in this study were only gender factors related to response time in $\mathrm{PI}$ triage, while age, education, length of work, and training are not related to response time in triage $\mathrm{PI}$ (Red), P2 (Yellow), or even P3 (Green). This shows that age, education, length of work, and training cannot guarantee nurses' response time in handling patients quickly. The motivational psychological factors of the respondents in this study did not have a significant relationship with the nurses' response time in triage PI (Red), P2 (Yellow), and P3(Green). This proves that the higher level of motivation of nurses does not guarantee that the response time in handling patients will be faster. Salary organizational factors in this study have a significant relationship with nurse response time in the $\mathrm{PI}$ triage category. As for the $\mathrm{P} 2$ and $\mathrm{P} 3$ triage response times, the salary factor does not have a significant relationship. This can explain that the higher salary given by the hospital will improve the performance of nurses in handling patients.

\section{Acknowledgement}

The authors wish to express their gratitude to all of staff Bangkalan Hospital, Sampang Hospital, Mohammad Noer Hospital Pamekasan, and Sumenep Hospital which contributed to assist the research.

\section{Conflict of Interest}

The authors declare no conflict of interest.

\section{Research Limitation}

The authors did not accompany respondents to fill the questionnaire, so it's possible that the answers were as a result of only a few respondents.

\section{Suggestions}

For implementing nurses, in this study nurses are expected to improve the quality of treatment in patients without considering the salary to be provided by the hospital. For the research sites, training for nurses, such as triage and emergency training, is urgently needed to hone nurses' abilities in handling patients in the ED. In addition, it is hoped that hospitals can increase documentation related to the number of patients in the ED based on the triage and speed category because this can be used as room evaluation material. This research can be developed for further research, focusing on variables in psychological factors, such as attitudes and perceptions, and organizational factors such as leadership.

\section{REFERENCES}

Afaya, AT., Azongo, and Yakong, VN. 2017. Perceptions and Knowledge on Triage of Nurses Workingin Emergency Departments of Hospitals in the Tamale Metropolis, Ghana. IOSR Journal of Nursing and Health Science (IOSR-JNHS), 6(3).

Akrian NT, Lucky K, R. M. (20I5). Hubungan Response Time Perawat dengan Tingkat Kecemasan Pasien Kategori Triase Kuning 
di IGD RSU Gmim Kalooran Amurang Tumbuan. Vol. 3, no. I. JURNAL KEPERAWATAN.

Amri, A., Manjas, M., \& Hardisman, H. (2019). Analisis Implementasi Triage, Ketepatan Diagnosa Awal Dengan Lama Waktu Rawatan Pasien di RSUD Prof. DR. MA Hanafiah SM Batusangkar. Jurnal Kesehatan Andalas, 8(3).

Apriani, A. (2017). Hubungan Kegawat Daruratan dengan Waktu Tanggap pada Pasien Jantung Koroner di RSI Siti Khadijah Palembang. Jurnal Kesehatan, 8(3), 47I.

Ardiyani, V. M., W, M. T. A., \& K, R. E. (20I5). Analisis Peran Perawat Triage Terhadap Waiting Time Dan Length Of Stay Pada Ruang Triage Di Instalasi Gawat Darurat Rumah Sakit Dr Saiful Anwar Malang. Care: Jurnal Ilmiah Ilmu Kesehatan, 3(I), 39-50.

Fadhilah, N., Harahap, W. A., \& Lestari, Y. (20I5). Faktor-faktor yang berhubungan dengan waktu tanggap pada pelayanan kasus kecelakaan lalu lintas di instalasi gawat darurat rumah sakit umum pusat $\mathrm{Dr}$ . M. Djamil. Jurnal Kesehatan Andalas, 4(I), I95-20I.

Gräff, I., Goldschmidt, B., Glien, P., Klockner, S., Erdfelder, F., Schiefer, J. L., \& Grigutsch, D. (2016). Nurse Staffing Calculation in the Emergency Department Performance-Oriented Calculation Based on the Manchester Triage System at the University Hospital Bonn.

Hakim, A., Julia, M. Y. K. (20I6). Analisis Perbedaan Response Time Perawat Terhadap Pelayanan Gawat Darurat Di Unit Gawat Darurat di RSU Gmim Pancaran Kasih dan di RSU Tk.III Robert Wolter Monginsidi Kota Manado | Abdul | JURNAL KEPERAWATAN.

Kementerian Kesehatan RI. (2009). Keputusan Menteri Kesehatan Republik Indonesia Nomor 856/Menkes/Sk/lx/2009 Tentang Standar Instalasi Gawat Darurat ( IGD ) Rumah Sakit.

Kushayati, N. (20I4). Analisis Metode Triage Prehospital pada Insiden Korban Masal (Mass Casualty Incident). Jurnal Ilmiah WUNY, I6(4).

Lulie, Y., \& Hatmoko, J. T. (20I7). Respon Time (Waktu Tanggap) Perawat Dalam Penanganan Kegawatdaruratan Di Instalasi
Gawat Darurat Rsu Pku Muhammadiyah Di Kabupaten Kebumen. Interdisciplinary Journal Of Linguistics; University of Kashmir , Srinagar,J\&K,INDIA.

Mahrur, A., Yuniar, I., \& -, S. (20I6). FaktorFaktor Yang Mempengaruhi Lamanya Waktu Tanggap Dalam Pelayanan Gawat Darurat di Instalasi Gawat Darurat Rsud Dr Soedirman Kebumen. Jurnal Ilmiah Kesehatan Keperawatan, I2(I).

Mahyawati, M. and W. (20/5). Hubungan Kegawadarratan Pasien dengan Waktu Tanggap Perawat di IGD RS PKU Muhammadiyah Yogyakarta.

Mahyawati, \& widaryati. (20I5). Hubungan Kegawadaruratan Pasien dengan Waktu Tanggap Perawat di IGD RS PKU Muhammadiyah Yogyakarta. Tesis. E-Jurnal Keperawatan (e-Kp), I 4.

Mario, Perez. 2015. Response Time to the Emergency Department (ED) and Its Effect on Patient Flow and Hospital Outcomes.

Nehme, Z., Andrew, E., Smith, K. 2016. Factors Influencing the Timeliness of Emergency Medical Service Response to Time Critical Emergencies.

Ningsih, K. (20I3). Buku Ajar Dasar-Dasar Keperawatan Gawat Darurat II. Jakarta: Salemba Medika.

Nursalam, N. (20I5). Metodologi Penelitian Ilmu Keperawatan 4th ed. P. P. Lestari, ed., Jakarta: Salemba Medika.

Oman, K. (2008). Panduan Belajar Keperawatan Emergensi. Jakarta: Penerbit Buku Kedokteran EGC.

Purba W, B. A. (2019). Hubungan Pengetahuan Perawat Tentang Triage dengan Triage Time di Ruang Instalasi Gawat Darurat Rumah Sakit Wilayah Kabupaten Jember. Skripsi, Universitas Jember, Jember.

Permenkes RI. 2018. Peraturan Kementerian Kesehatan RI tentang Standar Pelayanan Kegawatdaruratan.

Ricardo, P. et all. 2018. Response Time in the Emergency Service.

Yanti, W., Islam, A., \& Gaus, S. (20I2). FaktorFaktor Yang Berhubungan Dengan Ketepatan Waktu Tanggap Penanganan Kasus pada Response Time I di Ruangan Bedah dan Non-Bedah IGD RS DR. Wahidin Sudirohusodo. Tesis Universitas Hasanuddin, (3), I-13. 
Vitrise, M. Mulyadi RT. Malara. (20I4). FaktorFaktor Yang Berhubungan Dengan Response Time Perawat Pada Penanganan Pasien Gawat Darurat Di lgd Rsup Prof. $\mathrm{Dr}$. R. D. Kandou Manado. Jurnal Keperawatan UNSRAT, 2(2).

Wa Ode, Andi, A. (20I2). Faktor-Faktor Yang Berhubungan Dengan Ketepatan Waktu Tanggap Penanganan Kasus Pada Response Time .
Wehbe, JH., Pligeo, J. Sheater, S., Villamaria, F. 2014. System Based Interprofessional Simulation Based Training Program Increases Awarness and Use of Rapid Response Team.

Yumiati TR. (2018). Analisis Faktor Yang Berhubungan Dengan Response Time Perawat Di lgd Rsu Tipe C Di Kupang Berdasarkan Teori Kinerja Gibson. Skripsi. Universitas Airlangga, Surabaya 